\title{
Value Assessment of Ecosystem Service Functions of Xiamen Park Expo Garden
}

\author{
Ni Chenmin ${ }^{1}$, Qian Zhengming ${ }^{2}$ \\ ${ }^{1}$ College of International Finance and Trade, Zhejiang Yuexiu University of Foreign Languages, Shaoxing, China \\ ${ }^{2}$ School of Economics, Xiamen University, Xiamen, China
}

Email address:

cmni@163.com (Ni Chenmin)

\section{To cite this article:}

Ni Chenmin, Qian Zhengming. Value Assessment of Ecosystem Service Functions of Xiamen Park Expo Garden. International Journal of Environmental Monitoring and Analysis. Vol. 8, No. 1, 2020, pp. 1-10. doi: 10.11648/j.ijema.20200801.11

Received: January 13, 2020; Accepted: February 19, 2020; Published: March 2, 2020

\begin{abstract}
Xiamen Park Expo Garden, full name is Xiamen international expo garden, is located in Jimei Zhongzhou Island, Xinglin Bay Xiamen, the hometown of Mr. Chen Jiageng, the vast Xinglin Bay water area is the background. The planning area covers a total area of 10.82 square kilometers, including 5.55 square kilometers of land area and 5.27 square kilometers of water area. It is composed of 9 islands and 2 peninsulas. Since its construction in 2007, Xiamen Park Expo Garden has greatly promoted the development of tourism, ecological services and real estate in Jimei District of Xiamen City, and also greatly promoted the development of the surrounding economy. Using the method of ecological economics and mathematics analysis, such as carbon tax law, afforestation cost method, market value method, industrial oxygen production method, expense method, shadow engineering method, conditional value method and achievement reference method etc, some ecological services of Xiamen Park Expo Garden are valued, such as fixed carbon dioxide, release oxygen, air purification, water storage, tourism and leisure, education and scientific research, the real estate value. The total value is about 484 million, of which the value of tourism and leisure is the largest, it is 375.9766 million yuan, and occupies the proportion of $77.71 \%$. By analyzing the total value of the marginal effect of main components, some suggestions are proposed for the construction and development of Xiamen Park Expo Garden.
\end{abstract}

Keywords: Ecological Service Value, Ecological Accounting, Xiamen Park Expo Garden, The Marginal Value

\section{Introduction}

The value of ecosystem services is estimated by ecosystem services and natural capital of economic laws. The concept of ecosystem service was first put forward in 1970 [1]. In 1972 and 1974, Wilson [2] and Ehrlieh et al. [3] improved the concept of "ecosystem service" again, and studied the global environmental service function, pointing out that the destruction of biodiversity has a direct negative impact on the ecosystem service function. In 1997, American scholars Costanza et al. published the value of world ecosystem services and natural capital in the journal named Nature [4]. From the perspective of regional scale, they analyzed the value of 17 ecosystem service functions of 16 ecosystems on a global scale, and the research results showed that: Global ecosystem services value $\$ 33$ trillion, is $1.8 \sim 2$ times of global GDP, including wetland in accounts for only $6 \%$ of the surface of the earth to provide as much as $\$ 5$ trillion of the ecological service value. This discovery caused scholars research on wetland ecological service value of boom [7-28], also greatly improve the wetland on the ecology position. The value of ecological service function mainly includes four major aspects: adjustment function, cultural function, support function and supply function. Each of the major aspects can be subdivided into several items (as shown in table 1). These services interact and influence each other to jointly form their tourism value and promoting the economic development of the surrounding areas.

Table 1. Classification of ecosystem services.

\begin{tabular}{ll}
\hline First class & Second class \\
\hline Supply function & $\begin{array}{l}\text { Material production function } \\
\text { Climate regulation function Water storage and } \\
\text { soil conservation function } \\
\text { Scientific research and educational function } \\
\text { Tulturion function }\end{array}$ \\
$\begin{array}{l}\text { Touriond leisure function } \\
\text { Habitat function Nutrient cycling Real estate } \\
\text { appreciation function }\end{array}$ \\
\hline
\end{tabular}




\section{Brief Introduction of Xiamen Park Expo Garden}

Xiamen Park Expo Garden, full name is Xiamen international expo garden, is located in Jimei District, Xiamen, the hometown of Mr. Chen Jiageng, the "overseas Chinese flag". It is located in Jimei Zhongzhou Island, Xinglin Bay, Jimei District. The vast Xinglin Bay water area is the background. The water area originally belongs to the beach accumulation landform of the Bay, and then the closed reservoir is formed through the artificial construction of sea embankment, which is called Xinglin Bay Reservoir. The total area of Park Expo Garden Scenic Spot is 10.82 square kilometres, of which the land area is 5.55 square kilometres, the water area is 5.27 square kilometres, and the water area is close to half of the total garden area. It is the only water garden in the world. The Park Expo Garden Scenic Area is mainly composed of forests, grasslands and waters. The functional area planning is generally arranged in the form of peninsulas and islands. It consists of five exhibition islands, four ecological landscape islands and two peninsulas (Figure 1). It mainly includes the main exhibition area of the Expo, the Ecological Wetland Park, the China Education Park, the
Navigation Culture Park, the Hot Spring Island and other related supporting facilities. It is a famous lake, wetland and landscape tourism scenic spot. According to the data and literature of Xiamen meteorological observatory [5], the annual average temperature is $21.1^{\circ} \mathrm{C}$, the lowest monthly average temperature is $12.3^{\circ} \mathrm{C}$, the annual temperature is $16.0^{\circ} \mathrm{C}$, the annual rainfall is $1036 \mathrm{~mm}$, the climate is south subtropical monsoon climate, the climate is mild, the rainfall is abundant, and the life is comfortable. Since its construction, Xiamen Park Expo Garden has played a great role in promoting the development of tourism and service industry in Jimei district of Xiamen city, and also greatly promoting the development of the surrounding economy. From the perspective of ecological service value, this paper applies the method of ecological economics, mainly analyzes the accounting Xiamen Yuanbo wetland scenic area in the habitat in recent years, fix carbon release oxygen, purify air, dust retention, water storage, nutrient cycling, tourism and leisure, the value of ecological service functions such as education and scientific research, real estate value-added Propose and think the number of visitors' reduction, water environmental pollution problems.

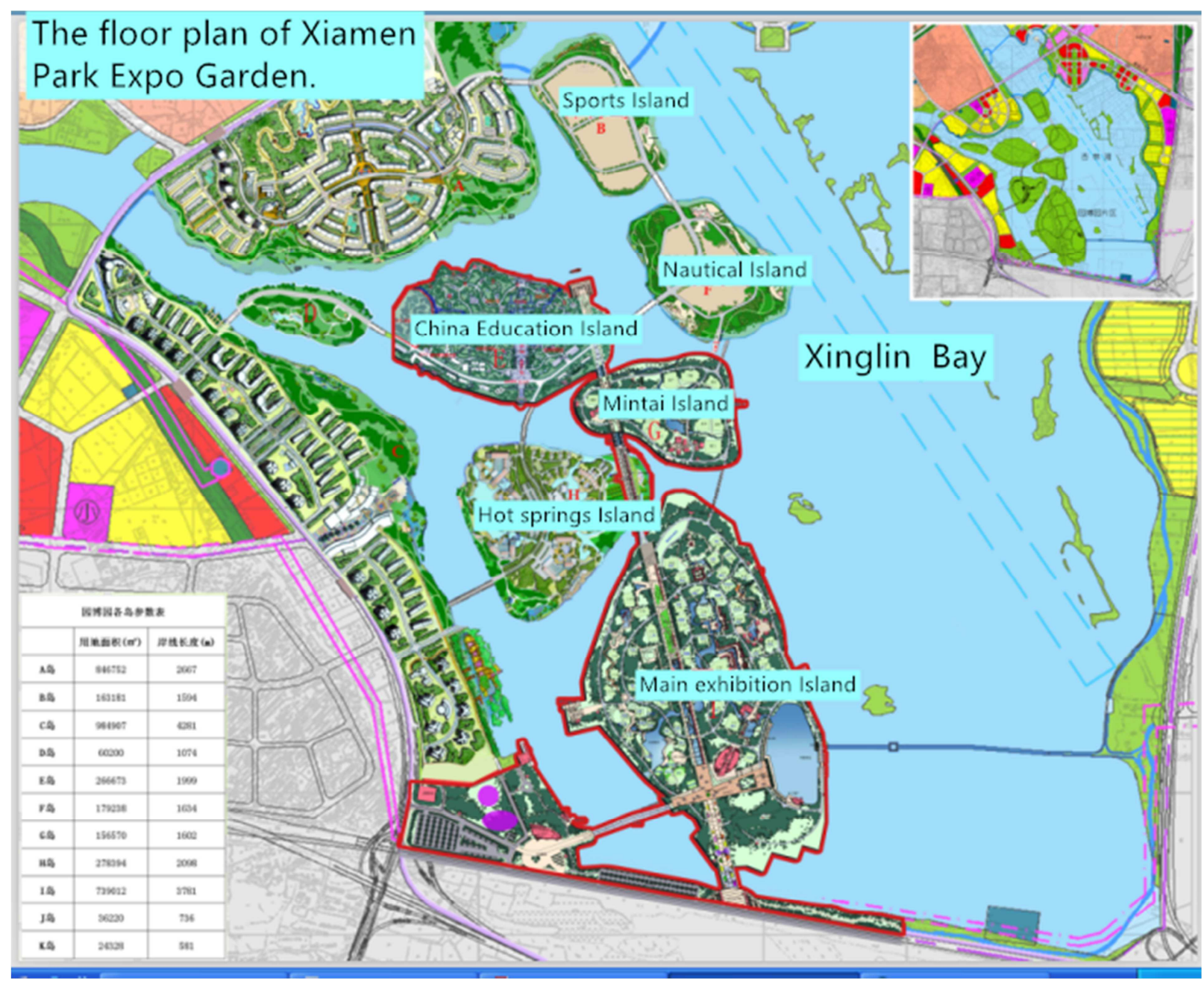

(The floor plan is from the garden management office of Xiamen Boyuan garden).

Figure 1. The floor plan of Xiamen Park Expo Garden. 


\section{Analysis and Accounting of Ecological Service Function Value in the Study Area}

\subsection{Study Method}

Combining with the characteristics of actual research area and the research object, mainly applicant carbon tax law, afforestation cost method, market value method, industrial oxygen method, cost method, shadow engineering method, travel cost method, conditions value method. The results of reference method and other research methods, their specific definition see Chinese description. Because of the wetland ecosystem service function value estimation methods have advantages and disadvantages, please see table 2 [8-9]. This article select and use methods according to the concrete situation, accordance with the preferred direct market method, secondary indirect market method. When both are not easy to get the conclusion, choose to simulate the marketing principles again.

Table 2. Comparison of different valuation methods.

\begin{tabular}{|c|c|c|c|}
\hline Classification & Evaluation methods & Advantages & Disadvantages \\
\hline \multirow{2}{*}{$\begin{array}{l}\text { Direct } \\
\text { marketing } \\
\text { method }\end{array}$} & Market value method & $\begin{array}{l}\text { The evaluation is objective, simple, less } \\
\text { controversial and reliable }\end{array}$ & $\begin{array}{l}\text { The data must be adequate and comprehensive, } \\
\text { without considering the indirect benefits }\end{array}$ \\
\hline & $\begin{array}{l}\text { Shadow engineering } \\
\text { method }\end{array}$ & $\begin{array}{l}\text { Intuitive; Alternative project cost, Reflect the } \\
\text { ecological value }\end{array}$ & $\begin{array}{l}\text { The alternative project is not unique and has great } \\
\text { difference in time and space }\end{array}$ \\
\hline \multirow{2}{*}{$\begin{array}{l}\text { Alternative } \\
\text { market method }\end{array}$} & Travel cost method & $\begin{array}{l}\text { It can evaluate the eco-environmental value without } \\
\text { market price, and convenient to calculate the } \\
\text { eco-environmental value roughly, and widely used }\end{array}$ & $\begin{array}{l}\text { It is impossible to calculate the non-use value in the } \\
\text { system, and there is no uniform standard for the travel } \\
\text { origin, and the tourism benefit is different. }\end{array}$ \\
\hline & $\begin{array}{l}\text { Achievement reference } \\
\text { method }\end{array}$ & Low application cost, convenient and fast & $\begin{array}{l}\text { There are certain requirements for the results of } \\
\text { reference, otherwise it may lead to incorrect results }\end{array}$ \\
\hline $\begin{array}{l}\text { Simulated } \\
\text { market method }\end{array}$ & $\begin{array}{l}\text { Conditional value } \\
\text { method }\end{array}$ & $\begin{array}{l}\text { Can evaluate various ecological service function's } \\
\text { economic value. It is suitable for the evaluation of } \\
\text { unique landscape and cultural relics }\end{array}$ & $\begin{array}{l}\text { Operation is difficult, requires a large sample size, and } \\
\text { sufficient time and funding }\end{array}$ \\
\hline Other categories & $\begin{array}{l}\text { Ecological value } \\
\text { method }\end{array}$ & $\begin{array}{l}\text { Objective assessment; It reflects the relationship } \\
\text { between ecological value recognition and economic } \\
\text { level. Readily available data }\end{array}$ & $\begin{array}{l}\text { The number of economic indicators involved is large; } \\
\text { it is not easy to compare the nuances of different } \\
\text { wetland conditions. }\end{array}$ \\
\hline
\end{tabular}

\subsection{Biodiversity Function}

Learned from Xiamen Park Yuanbo scenic area management office and Xiamen municipal bureau of parks and forests. According to the statistics of 2009 [11], there are 19 species and 15 families of rare plants in Xiamen Park Expo Garden scenic spot, including species of national first-class rare plants, 11 species of national second-class rare plants, one species of national third-class rare plants and 3 species of rare provincial plants. Trees were selected from 176 species of 48 families and 41,355 plants in public areas. According to the classified statistics of tree species planning and configuration, among the tree species as the keynote species, there are 31,046 trees of 20 species in the whole park, accounting for $75.07 \%$. There are 7171 tree species, accounting for $17.34 \%$ of 32 tree species. There were 122 tree species with 3138 plants, accounting for $7.59 \%$. In the selection and application of tree species, broadleaf trees are the main species, accounting for $76.47 \%, 31,626$ plants of 139 species of 41 families, 4149 plants of 7 species of conifers, accounting for $10.03 \%$, and 5 580 plants of 28 species of Palme, accounting for $13.5 \%$. Bamboo plants are also one of the main materials for plant configuration in Xiamen Park Expo Garden, which can be seen almost everywhere in the scenic spot. According to the statistics of Chen Songhe et al. [5] from 2010 to 2011, there are 10 general and 41 species of bamboo in Xiamen Park Expo Garden, and trees and bamboo are important raw materials for paper making industry. And, Xinglin bay in Park Expo Garden has abundant water resources, which provides favourable conditions for fish breeding, mainly ling fish, silver carp, herring, carp, crucian carp, tilapia. Almond-shaped bay reservoir is a large area of lakes, wind power is relatively smaller than the sea, which is the first selection of wintering waterfowl habitat, the shallow water area on the edge of the water body and suitable for wader's animal life, and the surrounding environment is covered by vegetation, and within the garden, garden vegetation coverage provide foraging and habitat condition for birds mainly has the common cormorants, heron, plovers, purple back starlings almond shaped bay waters community species diversity index is 3.66, ranked first in the coastal wetland bird community in Xiamen [12].

In this paper, use the results reference method to calculate the functions of biodiversity. The results reference method is a method to estimate the economic value of similar environmental service functions with the research results of one or more assessment methods, and after modification and adjustment apply it to the regional environment to be evaluated $[13,14]$. According to Xie Gaodi's et al. opinioned in [15] the biodiversity function of 2212.2 yuan in the 
ecosystem function assessment of China's terrestrial wetlands as the standard for the calculation of species habitat function value of Park Expo Garden. Then the functional value of species habitat of the garden is:

$$
5.55 \times 100 \times 2212.2 \approx 1.2278 \text { million yuan }
$$

\subsection{Fixed Carbon Dioxide, Releasing Oxygen Value}

In this paper, carbon tax law, afforestation cost method and industrial oxygen production method are used to calculate the value of fix dioxide and release oxygen in Park Expo Garden greenbelt. The carbon tax code, is a tax system set up by several countries to cut greenhouse gas emissions, is a way to determine the value of the loss of carbon dioxide by charging for its emissions. Afforestation cost method is to obtain the fixed amount and release amount of annual biomass according to the photosynthetic equation, and then convert the economic value of fixed pure $\mathrm{C}$ by combining the average cost of carbon sequestration afforestation in China, and obtain the economic value by combining the current price of domestic industrial oxygen [16-18]. The Swedish carbon tax rate is usually 150 $\mathrm{USD} / \mathrm{t}$ (proposed by Wibe in 1990). According to the exchange rate of 17:33 on July 15, 2016, the exchange rate of 1 USD is 6.681 yuan, equivalent to 1002.15 yuan/t; Industrial oxygen generation method is the basic principle of hypothesis of green oxygen is released by consists of an oxygen plant, according to the [16] [18]. China's industrial oxygen generation average costs is 400 yuan/t, afforestation of carbon sequestration in China cost is 260.9 yuan/t, afforestation cost is 325.93 yuan/t, according to this to calculate the average cost of fixed carbon is 631.53 yuan/t, the average cost of making oxygen is 362.97 yuan/t below will use the above data to calculate the value of fix carbon and release oxygen.

According to the scientific calculation of the Japanese forestry department [6], every square kilometre of forest can absorb $1600 \mathrm{t}$ of carbon dioxide and release $1200 \mathrm{t}$ oxygen through photosynthesis every year. According to the information obtained from Xiamen municipal bureau of parks and forests and relevant materials, the total greening area of the garden expo park is about 1.5 square kilometres at present. According to this can be calculated that:

The fixed carbon value of the greenbelt in Park Expo Garden is:

$$
1.5 \times 1600 \times 631.53 \approx 1.5157 \text { million yuan }
$$

The oxygen release value of the greenbelt of Park Expo Garden is:

$$
1.5 \times 1200 \times 362.97 \approx 0.6533 \text { million yuan }
$$

Every year, the total value of fixed carbon and oxygen release in Park Expo Garden is 2.169 million yuan.

\subsection{The Value of Purifying the Air}

Park Expo Garden scenic area near Jimei district irrigation mouth industrial zone, there have many factories, will discharge part of the poisonous gas and dust particles, and itself has a lot of harmful gases in the atmosphere, such as $\mathrm{O}_{3}$, $\mathrm{NO}_{2}, \mathrm{CO}, \mathrm{SO}_{2}, \mathrm{PM} 10$, of which the content of sulfur dioxide $\left(\mathrm{SO}_{2}\right)$ ), the largest of biological harm is great, green plants can absorb the harmful gas in the air, and purify the pollution of air. According to the study, in the area with $30 \%$ green coverage, the carcinogenic substances in the air can be reduced by $58 \%$ and sulfur dioxide reduced by more than $90 \%$. The air purification value of green space is mainly reflected in the degradation and purification value of air pollutants (mainly sulfur dioxide) and the benefit of sterilization and dust retention. Recovery fee is adopted here. Recovery fee method is used to estimate the cost of restoring the environment to its original state after it is destroyed. It can evaluate the value of urban green space absorbing toxic gas or dust retention and dust removal. Firstly, it is necessary to determine the cost of controlling toxic gas or dust. Secondly, determine the cost of controlling the toxic gas or dust per unit weight during the evaluation period. Finally, multiply these two together to get the total cost of cleaning up the toxic gas or dust absorbed by the green space.

(I) Purify the value of sulfur dioxide

According to the survey and statistics of the garden and expo park, trees are mainly selected for greening in public areas. In terms of tree species selection, broad-leaved trees account for $76.47 \%$, coniferous trees account for $10.03 \%$ and palm family accounts for $13.5 \%$ [11]. According to China's biodiversity research report [19] and literature of 16, 20-22, every year broad-leaved forest on sulfur dioxide absorbing ability is 215.60, coniferous forest average absorptive capacity is 88.65 , palm grove average absorptive capacity is 45.64, the cost of governance sulfur dioxide is about 600 yuan/ton, according to this to calculate the Park Expo Garden green space of a year the sulfur dioxide absorption quantity:

$$
1.5 \times 100 \times(215.60 \times 76.47 \%+88.65 \times 10.03 \%+45.64 \times 13.5 \%) \div 1000 \approx 26.99 \text { ton }
$$

The annual sulfur dioxide purification value of the green space in Park Expo Garden:

$$
26.99 \times 600 \approx 0.0162 \text { million yuan }
$$

(II) The value of retained dust

Green plants have a large leaf surface area, also known as the "green vacuum cleaner", has strong adsorption of floating in the air dust, According to the annual average dust retention capacity of coniferous forest, broad-leaved forest and coniferous and broad-leaved mixed forest measured 21.66, according to the dust removal operation cost of 170 yuan/ton [23], the annual dust retention benefit value of Park Expo Garden greenbelt is:

$$
21.66 \times 170 \times 1.5 \times 100 \approx 0.5523 \text { million yuan }
$$

From (I) (II), the annual air purification value of Park Expo Garden green belt is 568,500 yuan. 


\subsection{The Value of Water Supply and Storage}

This function mainly includes the water storage value of Park Expo Garden and the water conservation value of the green area.

(I) Water storage value

Park Expo Garden waters almond shaped bay area original belongs to is the gulf beaches accumulation landforms, 1956 by the artificial building apricot seawall became closed reservoir, the existing water area is about 5.27 square kilometres, learn from the results of the investigation and exploration [11], Park Expo Garden waters not much affected by the causeway bay outside the water of the sea, bay is still as fresh water, water isolation DiNa salinity in $0.6 \% \sim 0.8 \%$, change is small, and the farther deep the salinity is smaller, more suitable for the growth of plants. The normal water capacity is usually 6.43 million. After renovation and protection. It can be used as an emergency water supply for industry, agriculture and living water in Jimei district and Haicang district in case of special circumstances. According to the information obtained from Xiamen water supply and Xiamen municipal development and reform commission (Xiamen municipal development and reform commission price [2015] no. 1021), the tap water price in Xiamen is divided into three grades. The average price of tap water in the first and second grades is 2.75 Yuan/ton, as the water density is $1000 \mathrm{~kg} /$ ton. The total annual water supply value of the Park Expo Garden water area is:

$$
643 \times 2.75=17.6825 \text { million yuan }
$$

(II) The value of conserving water

The value of green space water conservation is mainly reflected in the increase of effective water quantity, improvement of water quality and regulation of runoff, which is positively correlated with green space volume. The larger the volume is, the stronger the capacity is. When the volume of the wetland is determined, the larger the precipitation and rain-bearing area is, the stronger the capacity of green land to conserve water is. First according to the water balance method (the basic principle of balance is the law of conservation of mass. The quantity of the water cycle represents the continuity of the water movement (including the phase transition) in the time domain space at any given scale, maintaining the balance of payments in quantity. Calculate the total amount of green water conservation, that is, the difference between green precipitation and evapotranspiration and other consumption. Here, we ignore other consumption and then use shadow engineering (that is looking for alternative markets for goods), Calculate the total amount of green belt water conservation, that is, the difference between green belt precipitation and evapotranspiration and other consumption. Here, we ignore other consumption, and then use the shadow engineering method (i.e., looking for alternative markets for goods, using the same product price on the market to estimate the value of the goods, using the artificial reservoir with storage function as the alternative project) to figure out the value of water conservation. The following formula is:

The value of water conservation in the greenbelt forest area of Park Expo Garden $=S \times(P-E) \times C$

$\mathrm{S}, \mathrm{P}$ and $\mathrm{E}$ respectively represent the green area (square kilometres), average annual precipitation ( $\mathrm{mm})$ and evapotranspiration ( $\mathrm{mm}$ ) of Park Expo Garden. $\mathrm{C}$ is the cost per unit storage capacity, which is 7 yuan. Combined with relevant literature $[21,25,26]$, the average annual evapotranspiration of the national forest is usually $56 \%$ of the annual precipitation of the green forest land. Assume that the annual evapotranspiration of the green land in Park Expo Garden is $60 \%$. According to information obtained from Xiamen meteorological bureau and Xiamen forestry bureau, the average annual rainfall in Park Expo Garden area is $1036 \mathrm{~mm}$, and the total greening area of Park Expo Garden scenic area is about 1.5 square kilometres, it can be obtained from the above data:

Annual water conservation value of green area forest in Park Expo Garden is:

\section{$1.5 \times 10^{6} \times 1036 \times 40 \% \times 10^{-3} \times 7 \approx 0.4351$ million yuan $(7)$}

The water supply and storage value of Park Expo Garden is 18.1176 million yuan.

\subsection{Nutrient Cycling Value}

Calculated according to the Ouyang Zhiyun [24] China indirect value of ecosystem nutrient cycling, calculated the ecological system $1 \mathrm{~g}$ per fixed carbon, can accumulate nitrogen $0.025426 \mathrm{~g}, 0.00201 \mathrm{~g}$ phosphorus and potassium. Take November 2015 Hengshui Hebei province NPK fertilizer to an average price of 2019 yuan/ton as a reference, by 3.3, to estimate the Park Expo Garden for nutrient cycling ecosystem service value is:

$$
1600 \times(0.025426+0.00201+0.01012) \div 3 \times 1.5 \times 2019 \approx 0.0607 \text { million yuan }
$$

\subsection{Tourism and Leisure Value}

Xiamen Park Expo Garden scenery is beautiful, water close to the island, Wetland Park, Hot Spring Island and regularly holds flower expo, garden expo, lantern fair attracting many tourists from other parts of the country. The cost expenditure method is usually adopted to estimate the value of leisure tourism, and the specific algorithm is [28], leisure tourism value $=$ travel cost expenditure + travel time value + consumer surplus. The travel expenses mainly include the direct and return transportation expenses from the origin to the scenic

spots, accommodation and food expenses during the journey, scenic spot tickets and various service fees. The value of travel time is obtained by multiplying the total time tourists spend in scenic spots by the opportunity wage cost per unit of time. The consumer surplus is generally about $10 \%$ of other expenses. The opportunity cost is generally $1 / 3$ of the wage cost. The average hourly wage in Xiamen in 2015 is 17.9 yuan according to the data checked by Xiamen local taxation bureau. Travel expense and the time duration of the tourists in the scenic spot, by questionnaire (start in may, 2016, distribute 200 
questionnaires, collect 183 questionnaires), it is worth noting that the 81 tourists surveyed is not from Xiamen, travel costs 500 yuan per capita, there are 102 people is Xiamen local residence, 80 of them have a tourism year card (free admission), 22 people entering through buy tickets, Park Expo Garden ticket is 60 yuan, plus the expenses of travelling by electric car or eating and so on, the average cost of travelling is about 238.5 yuan per person and 3 hours per person. According to the data obtained from Xiamen municipal bureau of parks and forests, from 2011 to 2015, the annual average number of tourists of Park Expo Garden was 1.4331 million, so the tourism and leisure value of Park Expo Garden was calculated as follows:

$$
143.31 \times\left[238.5+17.9 \times 3 \times 0.0001 \times \frac{1}{3}+(238.5+17.9 \times 3 \times 0.0001) \times 0.1\right] \approx 375.9766 \text { million yuan }
$$

\subsection{Educational Research Value}

Park Expo Garden scenic area of Chinese education park is the first in China with education as the theme of the landscape garden, the garden design style is unique, has the strong sense of history and appeal. To the comprehensive, focused, classical Chinese teaching blind cultural history and the present, expression of "inheriting Chinese nation long culture, promote the healthy growth of Chinese harmonious education", the theme of the attracted the lovers of primary and middle school students and the lovers of education research. Result reference method has been used here to calculate the educational and scientific research value of the Park Expo Garden. Using China's per unit area ecosystem and the average value of 382 dollars a year in [13] and [4] such as Costanza wetland ecosystems to global scientific research and education function value of $\$ 881$ a year (5885.96 yuan, according to the opening of the exchange rate on July 15, 2016, 6.681 yuan for 1 dollar) average of 3133.98 yuan/() as Xiamen Park Expo Garden per unit area of education scientific research value. The educational and scientific research value of the Park Expo Garden is:

$$
5.55 \times 100 \times 3133.98 \approx 1.7394 \text { million yuan }
$$

\subsection{Property Added Value}

Adopt investigation method, Xiamen Park Expo Garden

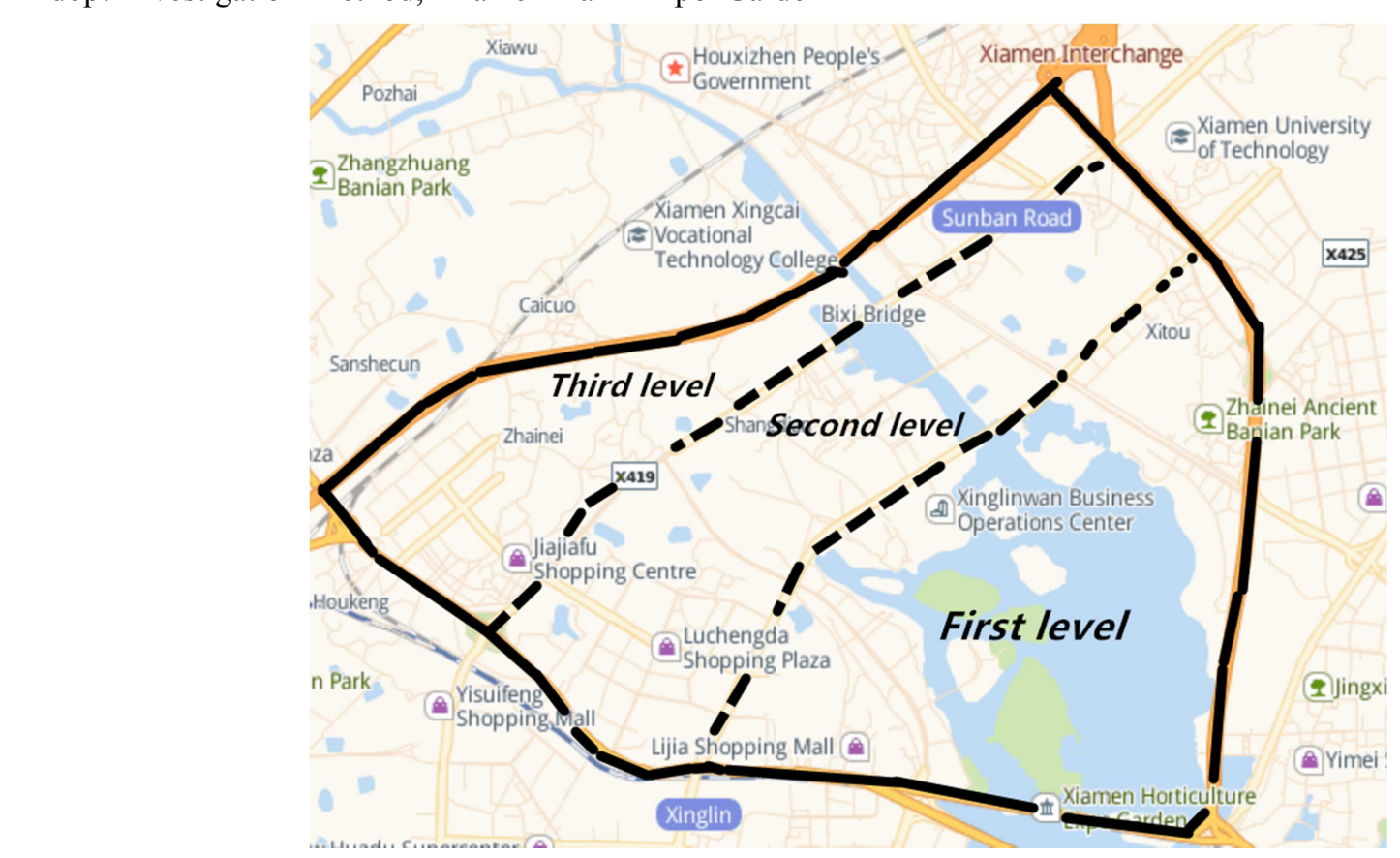

Figure 2. The different level classification of the lands surrounding Xiamen Park Expo Garden. since September 23, 2007 officially open to visitors, on October 8, 2007 land auction in Xiamen, Xiamen residential construction group with 1.6 billion Yuan get the 2007 jg03 plot of the plates of almond-shaped bay garden show park (now in plots of "garden, no. 1"), the floor price of 12066.37 Yuan/square meters, refresh the record of the Xiamen nonlocal piece of floor price, fully embodies Park Expo Garden's influence on the surrounding real estate. Later, there were "Zhonghangcheng", "oak bay", "IOI Yuanbo bay" and "longhu-Chun Jiang li cheng" on the west were developed. Eastside "crystal lake county" "waterfront one mile", "waterfront community" and the north "palm city", "lotus" series and other real estate were developed, And commercial housing prices grow with time, and Park Expo Garden built and improved. investigation and analysis shows that under the influence of without considering other factors, and the influence of Yuanbo on the surrounding land price has a two dimensional normal distribution characteristics, that is with the increase of Park Expo Garden centre distance, real estate appreciation will decline, but change range decrease with the distance increase, then flattened. Literature [6] divides the plots near Park Expo Garden into three levels according to the distance between the building and the centre of Park Expo Garden (see figure 2). 
And calculate three levels block 's house price from 2012 to 2014 as well as the average price of house, level classification method has been reffered, combining with the Xiamen city real estate network, Xiamen to guest information, as well as the results of actual investigation, telephone consultation, supplemented by some special unknown housing price and the situation of the three levels of 2015 block buildings and average price. In the third level median home price as a benchmark, calculated the Park Expo Garden in real estate appreciation value. The supplemented real estate situation around Xiamen Park Expo Garden in the past four years is as follows:

Table 3. The real estate table around Xiamen Park Expo Garden from 2012 to 2015.

\begin{tabular}{|c|c|c|c|c|c|c|}
\hline \multirow[b]{2}{*}{ Year } & \multicolumn{2}{|l|}{ The first level } & \multicolumn{2}{|l|}{ The second level } & \multicolumn{2}{|l|}{ The third level } \\
\hline & Property name & $\begin{array}{l}\text { Average price } \\
\left(y u a n / m^{2}\right)\end{array}$ & Property name & $\begin{array}{l}\text { Average price } \\
\left(y u a n / m^{2}\right)\end{array}$ & Property name & $\begin{array}{l}\text { Average price } \\
\left(y \text { uan } / \mathrm{m}^{2}\right)\end{array}$ \\
\hline 2012 & $\begin{array}{l}\text { Residence. Crystal lake } \\
\text { county, } \\
\text { Zhonghangcheng } \cdot \text { The } \\
\text { international community, } \\
\text { Residence. } \text { Park Expo } \\
\text { Garden No } 1\end{array}$ & 13800 & $\begin{array}{l}\text { Residence Lianhua } \\
\text { shangyuan (shop), } \\
\text { Lotus new town zhenyuan, } \\
\text { Residence·Lotus } \\
\text { international, } \\
\text { Juzhen, } \\
\text { China resources oak bay }\end{array}$ & 9700 & $\begin{array}{l}\text { Kangcheng fanglin, } \\
\text { University kangcheng } \\
\text { meiyu, } \\
\text { Xia shang epoch, } \\
\text { Phoenix huacheng }\end{array}$ & 7600 \\
\hline 2013 & $\begin{array}{l}\text { IOI palm city, } \\
\text { Residence. Crystal lake } \\
\text { county, } \\
\text { IOI Park Expo Bay, } \\
\text { Zhonghangcheng } \\
\text { international community, } \\
\text { Residence. Park Expo } \\
\text { Garden No } 1\end{array}$ & 17625 & $\begin{array}{l}\text { lianhua shangyuan (shop), } \\
\text { Lotus new town zhenyuan, } \\
\text { Residence-Lotus } \\
\text { international, } \\
\text { ZhonghaiJincheng } \\
\text { international } \\
\text { Juzhen, } \\
\text { China resources oak bay }\end{array}$ & 12717 & $\begin{array}{l}\text { University } \\
\text { Guangcheng · meiyu, Xia } \\
\text { Shang epoch, } \\
\text { Phoenix huacheng (The } \\
\text { average price of Phoenix } \\
\text { huacheng in } 2013 \text { was } \\
11,300 \text { yuan per square } \\
\text { meter) }\end{array}$ & 12433 \\
\hline 2015 & $\begin{array}{l}\text { IOI palm city } \\
19445 \\
\text { Residence. Crystal lake } \\
\text { county, } \\
19500 \\
\text { Zhonghangcheng } \\
\text { international community } \\
20000 \\
\text { Residence. Park Expo } \\
\text { Garden No } 1 \\
22000\end{array}$ & 20481 & $\begin{array}{l}\text { Residence lianhua world } \\
16000 \\
\text { China resources oak bay } \\
18300 \\
\text { Hengda emperor scene } \\
17940\end{array}$ & 17413 & $\begin{array}{l}\text { Xia shang epoch, } \\
16483 \\
\text { Phoenix huacheng } 12967\end{array}$ & 14725 \\
\hline
\end{tabular}

According to [26], from the time scale of regression model analysis infer the green park, the biggest impact on the surrounding real estate range is $2.6 \mathrm{~km}$, and from the space dimension of the regression model analysis infer green park affect prices around the maximum range for $1.59 \mathrm{~km}$. The authors take an average of them is $2.1 \mathrm{~km}$, because of the Park Expo Garden around the center, $1.5 \mathrm{~km}$ radius area is water area, distance is too close to the water's edge is not suitable for residential building. It is considered that Park Expo Garden scenic area's maximum radiation radius is $2.1 \mathrm{~km}+1.5 \mathrm{~km}=$ $3.6 \mathrm{~km}$. The range mainly includes the first level and second level area in figure 2, in fact, the results of our research conform to this conclusion, Park Expo Garden scenic area for the third level of regional value is very weak. There is little difference between the real estate price of the third level plot and that of Jimei plots far away from the Park Expo Garden. Therefore, we in the third level land prices as a benchmark, calculate the Park Expo Garden scenic area the added value of impact on the prices. Note $X_{i}, Y_{i}, Z_{i}, i=2012,2013,2014,2015$. Respectively represents the average housing price of the first, second and third level plots in the i year, that is:

Every year the added value of the Park Expo Garden scenic spot to the housing price of the surrounding land is:

$$
a \sum_{i=2012}^{2015}\left(X_{i}-Y_{i}\right) / 4+b \sum_{i=2012}^{2015}\left(Y_{i}-Z_{i}\right) / 4=a(6200+5192+5933+5756) / 4+b(2100+284+683+2588) / 4=5570.25 a+1413.75 b
$$

Among them $a, b$ is a year on average for the first level and second level land on the development of the housing area, Among them for a year on average for the first level and second level land on the development of the housing area, they depend on the floor height and degree of the development of the plot. Authors replace the abutment letters, from (11) it can be seen 
that marginal effect of price appreciation, the first level plot every increase 1 square meters, can increase the value of 5570.25 yuan, while the second level increase is only 1413.75 yuan, while the real estate price changes also affected by recent years the Xiamen city real estate natural increase and other factors (such as the price of the second and third level by the almond shaped bay municipal service center construction of the impact of price increases a lot), However, it can also be clearly seen that the driving effect of Park Expo Garden scenic spot on the surrounding real estate, If $a=10000 \mathrm{~m}^{2}, b=20000 \mathrm{~m}^{2}$, Then the annual value-added value of Park Expo Garden scenic spot to the surrounding land prices is:

$5570.25 \times 10000+1413.75 \times 20000=83.9775$ million yuan $(12)$

\section{Total Value and Analysis of Ecosystem Service of Xiamen Park Expo Garden}

Through the analysis of the third part, Xiamen Park Expo Garden of ecological service function value is about 484 million yuan, accounting for Xiamen, $0.13 \%$ of GDP in 2015 (356.5 billion yuan), accounted for $0.97 \%$ of GDP (49.4 billion) in 2015 in Jimei district, of which the tourism and leisure value, about 376 million, accounts for nearly $80 \%$ of the total ecosystem service value, followed by the real estate appreciation value, accounted for $17.36 \%$ of the total value. Other specific proportion information is shown in table 4 .

Table 4. Ecological service value of Xiamen Park Expo Garden.

\begin{tabular}{|c|c|c|c|c|c|c|c|c|}
\hline $\begin{array}{l}\text { Types of ecological } \\
\text { services }\end{array}$ & $\begin{array}{l}\text { Biological } \\
\text { diversity }\end{array}$ & $\begin{array}{l}\text { Fix carbon release } \\
\text { oxygen }\end{array}$ & Purify air & $\begin{array}{l}\text { Supply and } \\
\text { storage water }\end{array}$ & $\begin{array}{l}\text { Nutrient } \\
\text { cycling }\end{array}$ & $\begin{array}{l}\text { Tourism and } \\
\text { leisure }\end{array}$ & $\begin{array}{l}\text { Education } \\
\text { scientific research }\end{array}$ & $\begin{array}{l}\text { Real estate } \\
\text { appreciation }\end{array}$ \\
\hline methods & $\begin{array}{l}\text { Achievement } \\
\text { reference } \\
\text { method }\end{array}$ & $\begin{array}{l}\text { Carbon tax law } \\
\text { Shadow engineering } \\
\text { Afforestation cost } \\
\text { method } \\
\text { Industrial oxygen } \\
\text { production }\end{array}$ & $\begin{array}{l}\text { Usage of } \\
\text { recovery fee }\end{array}$ & $\begin{array}{l}\text { Water balance } \\
\text { method } \\
\text { Shadow } \\
\text { engineering }\end{array}$ & $\begin{array}{l}\text { Achievem } \\
\text { ent } \\
\text { reference } \\
\text { method }\end{array}$ & $\begin{array}{l}\text { Expense } \\
\text { method }\end{array}$ & $\begin{array}{l}\text { Achievement } \\
\text { reference method }\end{array}$ & $\begin{array}{l}\text { Survey } \\
\text { method }\end{array}$ \\
\hline $\begin{array}{l}\text { Proportion of the value } \\
\text { of each service }\end{array}$ & $0.25 \%$ & $0.45 \%$ & $0.12 \%$ & $3.74 \%$ & $0.01 \%$ & $77.71 \%$ & $0.36 \%$ & $17.36 \%$ \\
\hline
\end{tabular}

For information and accounting process into the problems found in the table, we found that the ecological service value of Park Expo Garden is influenced by four aspects, that is green areas, biological diversity, tourism and leisure, property value added 4 aspects, if the number of ecosystem service value for garden is Y (ten thousand yuan), green space area, biological diversity, the number of tourism and leisure per year, real estate appreciation number respectively because of carbon-oxygen release, purify air, water conservation, nutrient cycling function directly influenced by green areas, water storage value and the sum of the education scientific research value 18.9103 million yuan can be temporary as a constant, with reference to the third part of the discussion is

$$
Y=583.77 x_{1}+x_{2}+1891.03+\left(\frac{37597.66}{143.31}+a\right) x_{3}+x_{4}=583.77 x_{1}+x_{2}+(262.35+a) x_{3}+x_{4}+1891.03
$$

Among them $0<x_{1}<5.55$ the square kilometers; Added value of comfort and supporting facilities; In order to ensure tourism comfort, Gulangyu has a daily upper limit of 30,000 people, while Gulangyu covers an area of 1.78 square kilometres. According to this ratio and relevant literature [27, 28], the upper limit of daily visitors of Park Expo Garden is 93,500 , so $0<x_{3}<34.1275$ million. The number of tourists and leisure $x_{3}$ is mainly related to the propaganda, local transportation and leisure facilities in the park. By comparing the average annual number and scope of 1.4331 million in the paper, it can be seen that the tourism and leisure value of Park Expo Garden has great potential to be developed. What needs to be paid attention to is that the number of tourists living in Park Expo Garden has been decreasing year by year in the past five years, which needs special attention. The real estate appreciation $x_{4}$ depends on the greening and leisure facilities of the park. However, due to the limited land, it will gradually approach a stable value, so the real estate appreciation value of Park Expo Garden makes a small contribution to maintaining the sustainable development of the ecology. Reason to upgrade the ecological service value of Park Expo Garden, should be mainly from the $x_{1}$ and $x_{3}$ the affected and aspects, from (13), Y, respectively, and the partial derivative $x_{1}$ and $x_{3}$, can have both the marginal value were 583.77 and $262.65+(\mathrm{a})$, the study found that green area, small range, and is limited by public facilities construction to the contradiction of land (both and 5.55 square kilometres, need reasonable balance), the number of tourists growth potential, and with greater weight ascending garden, garden of ecological service value (especially the number of tourists). Therefore, we put forward the following three Suggestions:

(1) Increase the proportion of the green area is conducive to improving the ecological service value of Park Expo Garden. Every one square kilometre increase can gain an additional 5.83777 million Yuan of ecological 
service value. At the same time, the greening rate can increase the tourist comfort level and improve the leisure and health index of people around. In the tourists and people around the publicity, increase the attraction;

(2) Increase the propaganda dynamics, in the north station of the underground passage, increase billboards around the wall and optimize the garden, garden surrounding traffic construction, for example, increase from Xiamen north station bus for Park Expo Garden, increase from Xiamen university institute of technology, Xiamen engineering area buses for Park Expo Garden, provide convenience for tourists.

(3) Strengthen the construction of supporting facilities of Park Expo Garden, increase the attraction, such as optimizing the construction of Xinglin bay water area, do well in water entertainment activities, often engage in activities in the park, attract shops (such as famous products discount) to live around or inside Park Expo Garden, increase the fun of public tourism and leisure.

\section{Conclusions and Prospects}

(1) Based on the research of the Park Expo Garden ecological service system we can found that the top three of the ecological service value respectively is tourism and leisure, real estate appreciation value, water supply reservoir, especially the tourism and leisure value more than $70 \%$, in accordance with the Park Expo Garden construction goal "to build a collection of garden show, leisure, culture, entertainment and education as one of the theme park" basic agreement; Besides reflecting the service value of Park Expo Garden, the ratio of real estate appreciation also reflects the "soaring" speed of housing price in Xiamen in recent years. The water supply and storage value are mainly reflected in the strong water storage and water supply capacity of Xinglinwan reservoir in Park Expo Garden.

(2) Ecosystem services evaluation is a multi-disciplinary comprehensive research field, closely with the local natural geographic, economic and social situation picture frames, the current evaluation system is not perfect enough. For Park Expo Garden built time is short, greening area and the Non-greening area supporting facilities is not very perfect, the construction of each island is in constant innovation and update, the reason of our ecosystem service value accounting has a certain reference value, but not accurate enough, need to further optimize the evaluation index, detailed evaluation criteria. How to optimize the construction of land resources, achieve a relative balance between the value of ecological services and profits, and promote the natural, harmonious and sustainable development of Xiamen Park Expo Garden and its surrounding areas are still needed to be considered.

\section{References}

[1] SCEP (Study of Critical Environmental Problems). Man s 'impact on the Global Environment: Assessment and Recommendations for Action [M] Cambridge, MA: MIT Press, 1970.

[2] Holder J, Ehrlich P r. Human Population and Global Environment [J]. American Scientist, 1974, 62: 282-297.

[3] Wilson C L, Matthews W h. Man's Impact on the Global Environment: Assessment and Recommendations for Action [M]. Cambridge: Massasuchsetts Institute of Technology, 1972.

[4] Costanza R and d 'Arge R, DE Groot R, etal. The value ofthe world's ecosystem services and natural capital [J]. Nature, 1997 387 (15): 253-260

[5] Chen songhe, zhang wanqi, huang quanquan et al., the status and role of Xiamen park expo park in urban regional real estate economy [J], Sichuan forest industry science and technology, February 2016, vol. 37, no. 1: 107-110.

[6] YU Yina, PENG Shaolin. Review on evaluation of ecosystem services [J]. Ecology and Environment Sciences, 2010, 19 (9): 2246-2252.

[7] Tan Ming Ming, Duan Zheng Hu, et al. $\{\mathrm{J}\}$ evaluation of service value of urban artificial forest ecosystem in semi-arid area, China desert. January 2012, Vol. 32, No. 1: 220-225.

[8] Xu Xiaoyan, Case study on ecological value assessment of lakes and wetlands in main urban areas of Chongqing [D], Chongqing normal university, 2012.

[9] Zhang hao, Zhang ye, Heihe wetland nature reserve, research on ecological service function value [D], gansu agricultural university, June, 2006.

[10] Zhou Bingbing, Li Zhongkui. Value of forest resources in Beijing [M]. Beijing: China forestry press, 2000.

[11] Chen Shuilong, Application and planting of green trees in public areas of Xiamen garden expo park [J], forest survey and design, 2009.02: 102-106.

[12] Fang wenzhen, Chen xiaolin, Chen zhihong et al. Study on bird community diversity in Xiamen coastal wetland [J]. Journal of Xiamen University (natural science edition), vol. 43, no. 1, January 2004: 133-137.

[13] Chen zhongxin, zhang xinshi. The value of ecosystem benefits in China [J]. Science bulletin. 2000, (11): 17-22.

[14] Wang yan. Research on methods and applications of regional environmental value accounting [D]. Qingdao: ocean university of China, 2006: 28.

[15] Xie Gaodi, Lu Chunxia, lengyunfa, etc. Valuation of ecological assets on the qinghai-tibet plateau [J], journal of natural resources, 2003.03: 189-195. (in Chinese)

[16] Chen bo, Lu shan, Evaluation of greenbelt ecological service function value of Hangzhou west lake scenic spot [J], journal of Zhejiang university (agriculture and life science edition) [J], 2009: 35 (6): 686-690.

[17] Han yongwei, Gao Xinting, Gao Jixi etc. Construction of typical ecological services and evaluation index system in important ecological functional areas [J]. Journal of ecological environment, 2010, 19 (12): 2986-2992. 
[18] Ma Zhandong, Gao Hang, Yang Jun, etc., Evaluation of service function of Nansihu wetland ecosystem based on multi-source data fusion $[\mathrm{J}]$, resources and environment, 2014, 36 (4): 0840-0847

[19] The compilation group of national research report on biodiversity in China. National research report on biodiversity in China [M]. Beijing: China environmental science press, 1998.

[20] Jin fang, Lu Shaowei, Yu Xinxiao, et al. Forest ecosystem service function and its value evaluation in China [J]. Journal of applied ecology, 2005, 16 (8): 1531-1536.

[21] Duan Yanbo, Lei Yakai, et al. Evaluation and dynamic research on ecological service value of greenbelt system in Zhengzhou [J]. Ecological science, 2016, 35 (2): 81-88.

[22] Li Guangdong, Fang Chuanglin, Quantitative identification and analysis of urban eco-production-living space functions, journal of geography, 2016.01: 49-65.

[23] MAO wenyong, bai xuanhong, li zhong. Resource and environment data manual $[\mathrm{M}]$. Beijing: China science and technology press, 1992.
[24] Ouyang zhiyun, wang rusong, zhao jingzhu. Ecosystem service function and ecological economic value evaluation [J]. Journal of applied ecology, 1999, (5): 635-640. (in Chinese with English abstract)

[25] Xu hong, Zhao Pengda, Wu Junmei, et al., Valuation of west lake ecosystem services in Hangzhou [J], progress in water science, 2013.05, vol. 24, no. 3: 436-441.

[26] Shi Yishao, Zhang rui, Spatial-temporal effect of large park greenbelt on housing price -- a case study of Huangxing park greenbelt in Shanghai [J], geographical research, March 2010, vol. 29 , no. 3: 511-520.

[27] Wei Zhihong, Liu Youhua, Zhang Lidong, Research on the maximum capacity of theme park [J], special economic zone economics, 2014.02: 143-148.

[28] Xiang Yunyun, Meng Jijun, Progress in research and application of ecological carrying capacity [J], journal of ecology 2012, 31 (11): 2958-2965. 